\title{
The timing and duration of HT-UHT metamorphism constrained by zircon U-Pb-Hf and trace element signatures
}

SHUJUAN JiAO ${ }^{1}$, JiNGHUI GUO ${ }^{1}$, NOREEN J. EVANS ${ }^{2}$, BRAD J. MCDONALD ${ }^{2}$, PENG LiU ${ }^{1}$, DONGJiAn OUYANG ${ }^{1}$, IAN C. W. FITZSIMONS ${ }^{2}$

${ }^{1}$ State Key Laboratory of Lithospheric Evolution, Institute of Geology and Geophysics, Chinese Academy of Sciences, Beijing 100029, China ${ }^{2}$ School of Earth and Planetary Sciences, Curtin University, Perth 6102, Australia

We investigate a suite of high-grade rocks from the Khondalite Belt of the North China Craton, using zircon $\mathrm{U}-\mathrm{Pb}$ geochronology, and trace element and $\mathrm{Hf}$ isotopic signatures to track zircon behavior and constrain the timing and duration of metamorphism. Heavy rare-earth element (HREE) features from zircon in garnetiferous leucogneiss best record zircon behavior. Our results indicate zircon growth/recrystallization during prograde metamorphism at 1.92-1.90 Ga, protracted zircon growth/recrystallization during a retrograde cooling stage at 1.87-1.82 Ga, and zircon growth during local garnet breakdown at ca. $1.84 \mathrm{Ga}$. The virtual absence of zircon in the time gap between 1.90 and $1.87 \mathrm{Ga}$ likely constrains the timing of thermal peak at Dongpo locality in Daqingshan Terrane. This work indicates that the long-lived post-peak cooling stage at 1.87-1.82 Ga with ca. 50 myr. is more conspicuous in this part of the Khondalite Belt than the others. This probably reflects regional differences in cooling and exhumation rate during Nuna/Columbia amalgamation. 